\title{
A partial cDNA sequence of the ovine insulin receptor gene: evidence for alternative splicing of an exon 11 region and for tissue-specific regulation of receptor isoform expression in sheep muscle, adipose tissue and liver
}

\author{
P D McGrattan ${ }^{1}$, A R G Wylie ${ }^{1,2}$ and A J Bjourson² \\ ${ }^{1}$ The Queen's University of Belfast and ${ }^{2}$ The Department of Agriculture for Northern Ireland, The Agriculture and Food Science Centre, Newforge Lane, \\ Belfast BT9 5PX, UK \\ (Requests for offprints should be addressed to P McGrattan who is now at Northern Ireland Regional Genetics Centre, Belfast City Hospital Trust, \\ Lisburn Road, Belfast BT9 7AB, UK)
}

\begin{abstract}
Insulin is as integral and important to the management of metabolism in ruminants as it is in non-ruminants. The suggestion of a lowered ruminant sensitivity and/or responsivity to insulin may relate more to the insulin receptor than to the hormone itself. We screened an ovine cDNA library using degenerate primers and polymerase chain reaction (PCR) to detect and sequence a cDNA portion corresponding to exons 10, 11 and 12 of the human insulin receptor gene in which a 36 base pair (bp) segment (exon 11) is alternatively spliced to produce two distinct receptor isoforms differing in functional characteristics including binding affinity for insulin. The ovine cDNA segment (nucleotides 671 to 770 ) displayed 84, 84, and $78 \%$ nucleotide homology to equivalent segments from the human, rhesus monkey and rat respectively. Reverse transcription PCR (RT-PCR) of selected tissues (liver, $\mathrm{m}$. longissimus dorsi, $\mathrm{m}$. rectus capitis and omental, perirenal and subcutaneous fats) taken at slaughter from three male, pure Dutch Texel lambs (experiment 1) and five male Texel-Greyface crossbred lambs (experiment 2) revealed two mRNA products in each tissue (including spleen; experiment 2 only) corresponding to cDNAs of molecular sizes 161 and $197 \mathrm{bp}$ - a difference of $36 \mathrm{bp}$. Sequence alignment showed the $36 \mathrm{bp}$ segment to be homologous to the alternatively spliced exon 11 region of
\end{abstract}

the human insulin receptor gene and to be highly conserved with that from other species. The abundance of the exon $11^{+}$isoform in the purebred Texel genotype was significantly higher in liver than in perirenal fat and rectus capitis and longissimus dorsi skeletal muscles $(P<0 \cdot 05)$ and higher also than in subcutaneous and omental fats $(P<0 \cdot 01)$. There was, however, no difference in the abundance of the exon $11^{+}$isoform between the individual muscle and fat depots in this sheep genotype. The abundance of the exon $11^{+}$isoform in the crossbred Texel genotype was significantly higher in liver $(P<0 \cdot 05)$ than in the muscles (rectus capitis, $P<0 \cdot 05$; longissimus dorsi, $P<0 \cdot 001)$, all three fats $(P<0 \cdot 001)$ and spleen $(P<0 \cdot 001)$. In the crossbred genotype, the abundance of the exon $11^{+}$ isoform was higher in skeletal muscle than in all three fat depots $(P<0 \cdot 001)$, in which the isoform abundance was similar. Altered ratios of expression of the two products of this alternative splicing event could determine tissue sensitivity and/or responsivity to insulin and provide a mechanism for the management of nutrient partitioning and nutrient utilisation between tissues which is fundamental to the growth of tissues and manipulation of carcass characteristics in meat-producing animals.

Journal of Endocrinology (1998) 159, 381-387

\section{Introduction}

Little glucose is absorbed from the gut of domesticated ruminants (cattle, sheep, goats) which feed largely on forage diets occasionally supplemented with variable levels of energy concentrates such as barley or maize and protein concentrates such as extracted soya bean, sunflower seed or fish meals. Most glucose entering the rumen directly in the diet or released by intra-ruminal digestion of complex forage carbohydrate is metabolised to a number of short-

chain fatty acids (acetic, propionic, butyric and valeric) by a mixed microbial and protozoal population in the rumen. Only when energy concentrates are fed in large amounts, or in protected form, do significant quantities of glucose survive ruminal breakdown and become available for post-ruminal (i.e. ileal) absorption (Nocek \& Tamminga 1991).

Despite the paucity of glucose absorbed from the gut of the traditionally-fed ruminant, the ruminant animal has needs for glucose similar to those of non-ruminants (i.e. an 
obligatory requirement for brain function and a variable requirement for the conventional pathways of cellular metabolism) and glucose demand in ruminants is met largely by hepatic gluconeogenesis. Blood glucose concentration (typically $3-6 \mathrm{mM}$ ) in ruminants is regulated by the actions of the same counter-regulatory hormones (insulin and glucagon) as in non-ruminants and glucose is moved into both ruminant muscle (Hocquette et al. 1995) and adipose cells (Hocquette et al. 1996) by the same insulinresponsive glucose transporter (GLUT 4) as a consequence of insulin binding to receptors in the cell membrane. While the principal substrate for fatty acid synthesis in ruminants is acetate of ruminal, rather than glycolytic origin, glucose provides both the glycerol component for triacylglycerol synthesis and the NADPH required for the reductive steps of fatty acid synthesis. The interrelated metabolic processes of gluconeogenesis, glycolysis, fatty acid synthesis, lipolysis and protein synthesis and catabolism are all under the partial control of insulin in ruminants as in non-ruminants.

Overall, therefore, insulin is as integral and important to the management of metabolism in ruminants as in nonruminants. However, ruminants are often regarded as being less sensitive and/or responsive to insulin than non-ruminants (Vernon et al. 1985, Sasaki 1989). Sensitivity and responsiveness to a hormone are related to the hormone's interaction with its receptor and/or to postreceptor events (Kahn 1978) and the affinity of a receptor for its hormone is likely to be fundamental to both sensitivity and responsiveness.

The affinity of the insulin receptor for insulin has been shown by classical hormone-binding studies to differ between pig breeds (Camara \& Mourot 1996) and between tissues in humans (Bolinder et al. 1983, Kotzke et al. 1995) and in the ruminant (McGrattan et al. 1997, Wylie et al. 1998). Differences in insulin binding affinity $\left(K_{\mathrm{d}}\right)$ between liver, muscle and fat of sheep (Wylie et al. 1998) may underlie altered tissue responsiveness to insulin, but it is unclear how or why differences in insulin binding affinity between tissues arise. One possibility is manipulation of the ratio of expression of receptor isoforms, of innately different affinity for insulin, generated by alternative splicing (Breitbart et al. 1987) of a single insulin receptor gene as shown in humans (Moller et al. 1989, Seino \& Bell 1989), rats (Goldstein \& Dudley 1990) and the rhesus monkey (Huang et al. 1994). In each of these species, the insulin receptor is expressed as two isomeric products (A and B) of two mRNAs (exon $11^{+}$and exon $11^{-}$) which differ only in the presence or absence of a 36 base pair (bp) exon 11 region. Importantly, the A and B isoforms of the human insulin receptor differ in affinity for insulin $(A>B)$ when expressed in cultured cell lines (Mosthaf et al. 1990).

Differences in affinity for insulin between tissues may influence the partitioning of nutrients between tissues (e.g. muscle and fat) and affect their relative rates of growth.
This has potential, but clear, implications for the regional distribution of fat in humans and animals and for the manipulation of carcass composition (e.g. fat vs lean) in meat-producing animals.

\section{Materials and Methods}

Isolation of ovine insulin receptor $\mathrm{CDNA}$ and demonstration of two alternatively spliced $m R N A s$

Sense and antisense degenerate PCR primers encoding amino acids highly conserved in human, rat and mouse insulin receptor exon 10 and exon 12 respectively were used to screen an ovine omental adipose cDNA library (a gift from the Hannah Research Institute, Ayr, Scotland, UK). The sense primer (S1) consisted of a 20-mer with the sequence 5'-CARAARCAMAAYCARTCIGARTA-3' encoding the exon 10 amino acid sequence QKHNQSEY, while the antisense primer (AS1) was a 20-mer with the sequence 5'-AARCCITGGACICARTAYGCIAT$3^{\prime}$ encoding the exon 12 amino acid sequence KPWTQYAI.

PCR was performed in a $25 \mu \mathrm{l}$ reaction volume using Ready-to-Go PCR beads (Pharmacia Biotech, St Albans, Herts, UK) containing $200 \mu \mathrm{M}$ of each dNTP, $1.5 \mathrm{mM}$ $\mathrm{MgCl}_{2}, 10 \mathrm{mM}$ Tris, $\mathrm{pH} 9 \cdot 0,50 \mathrm{mM} \mathrm{KCl}$ and $0 \cdot 5$ units of AmpliTaq DNA polymerase, $5 \mu \mathrm{l}$ ovine cDNA and $2 \mu \mathrm{l}$ $(40 \mathrm{pmol})$ of each sense (S1) and antisense (AS1) degenerate primer. Each cycle consisted of denaturation at $95{ }^{\circ} \mathrm{C}$ $(1 \mathrm{~min})$, annealing at $52^{\circ} \mathrm{C}(1 \mathrm{~min})$ and DNA polymerisation at $72{ }^{\circ} \mathrm{C}(2 \mathrm{~min})$ in an automated thermal cycler (Model 2400, PE Biosystems, Warrington, Cheshire, UK). The final cycle included an incubation at $72{ }^{\circ} \mathrm{C}$ for $7 \mathrm{~min}$.

Amplified PCR products were analysed by gel electrophoresis using $2 \%(\mathrm{w} / \mathrm{v})$ high resolution agarose (Sigma Chemical Co., Poole, Dorset, UK) in $1 \times$ Tris acetate buffer (TAE; 0.089 M Tris, 0.089 $\mathrm{M}$ acetic acid, 0.002 M EDTA, pH 8.0). Appropriate PCR products were purified by 'band-stab' PCR (Bjourson \& Cooper 1992) and both strands were sequenced in triplicate using an automated ABI 373 sequencer (PE Biosystems). The nucleotide sequence and deduced amino acid sequence data were compared with sequences deposited in the EMBL and SWISSPROT databases using the BLASTn and BLASTx programs (Altschul et al. 1990).

Investigation of tissue-specific expression of alternatively spliced insulin receptor isoforms in sheep

Experiment 1 Three male Dutch Texel lambs were fed a diet of dried-grass nuts available ad libitum from weaning until slaughter at 8 months of age (slaughter weight= $47 \pm 0.5 \mathrm{~kg}$ ). Samples of liver (L), m. longissimus dorsi (LD), m. rectus capitis (RC) and subcutaneous (SCF), 
(A)

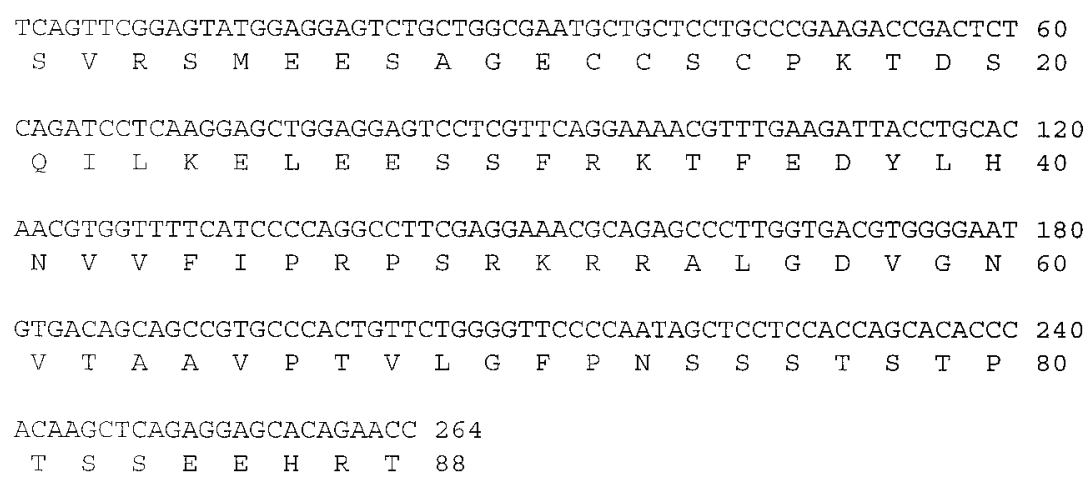

Figure 1 Partial nucleotide and deduced amino acid sequences of isoforms of the ovine insulin receptor gene. (A) Exon 11- (nucleotides 1-141: exon 10; 142-264: exon 12) and (B) exon $11^{+}$(nucleotides 1-141: exon 10; 142-177: exon 11; 178-300: exon 12). Nucleotide number and amino acid residue number are shown on the right. The alternatively spliced exon 11 region (base pair numbers 142 to 177 and amino acid numbers 48 to 59 ) is shown in bold and underlined in (B).

omental (OF) and perirenal (PF) fats were collected as soon as possible after captive-bolt slaughter and were immediately frozen in liquid nitrogen prior to storage at $-70{ }^{\circ} \mathrm{C}$. Total RNA was isolated from $20 \mathrm{mg}$ of the appropriate tissue using TRIzol reagent (Gibco BRL, Paisley, Strathclyde, UK) according to the manufacturer's protocol.

Experiment 2 Five male crossbred (0.75 Texel:0.25 Greyface) lambs were grazed on a ryegrass pasture from weaning until 5 months of age (mean liveweight of $32 \cdot 5 \pm 2 \mathrm{~kg}$ ) and then fed a $24-\mathrm{h}$ wilted grass silage available ad libitum until slaughter at 8 months of age (slaughter weight $=36 \cdot 0 \pm 4.6 \mathrm{~kg}$ ). Samples of L, LD, RC, $\mathrm{SCF}, \mathrm{OF}, \mathrm{PF}$ and spleen (S) were collected as soon as possible after captive-bolt slaughter and were immediately frozen in liquid nitrogen prior to storage at $-70{ }^{\circ} \mathrm{C}$. Total RNA was isolated from $20 \mathrm{mg}$ of the appropriate tissue using TRIzol reagent (Gibco BRL) according to the manufacturer's protocol.

\section{Isolation and reverse transcription of total RNA}

Reverse transcription-PCR (RT-PCR) was performed essentially according to Sesti et al. (1994) using sense and antisense oligonucleotides designed against the determined ovine specific insulin receptor nucleotide sequence (EMBL accession no. Y16092). The primers were designed to yield products of 161 and $197 \mathrm{bp}$ for the A and $\mathrm{B}$ insulin receptor isoforms respectively. First strand cDNA synthesis was performed using 200 units Superscript II reverse transcriptase (Gibco BRL) and total RNA $(12 \mu \mathrm{l})$ from the appropriate tissue. The RNA was denatured at $65^{\circ} \mathrm{C}$ for 5 min along with 2 pmol ovine speciesspecific antisense primer CA1 (5'-GTGGGCACGGCT GCTGTCAC-3' corresponding to exon 12 amino acids 


\begin{tabular}{|c|c|c|}
\hline Ovine & 671 & ------ SVRSMEESAGECCSCPKTDSQ \\
\hline Human & 671 & ------- NQSEY $--------\cdots---$ \\
\hline Monkey & 671 & ------- NQSEY $-\mathrm{D}---------\mathrm{N}--$ \\
\hline Rat & 673 & ------- NQSEYDD - -S - - - - - - - \\
\hline Mouse & 673 & $----\cdots-$ NQSEYDD $--S-\cdots-----$ \\
\hline Ovine & 692 & ILKELEESSFRKTFEDYLHNVVFIPRKSSS \\
\hline Human & 692 & $-\cdots------------------V---\mathrm{T}--$ \\
\hline Monkey & 692 & $----------+--------\mathrm{V}---\mathrm{T}--$ \\
\hline Rat & 694 & $---------------------\mathrm{V}---\mathrm{T}--$ \\
\hline Mouse & 694 & $------------\infty--------\mathrm{V}---\mathrm{T}--$ \\
\hline Ovine & 722 & GPVAEDARPSRKRRALGDVGNVTAAVPTVL \\
\hline Humar & 722 & $-\mathrm{TG}---\mathrm{P}-\cdots---\mathrm{S}----\cdots-\mathrm{V}-\cdots--\mathrm{A}$ \\
\hline Monkey & 722 & $-\mathrm{TG}---\mathrm{P}-----\mathrm{S}------\mathrm{V}----\mathrm{A}$ \\
\hline Rat & 724 & $-N G---T-----S-E E-\cdots---T T--L P$ \\
\hline Mouse & 724 & $-\mathrm{NG}---\mathrm{S}------\mathrm{S}-\mathrm{EE}-\cdots--\mathrm{TTL}-\mathrm{LP}$ \\
\hline ovine & 752 & GFPNSSSTSTPTSSEEHRT \\
\hline Human & 752 & A-- - T----V-- PEEHRPFEKVVNKESLV \\
\hline Monkey & 752 & A-- - T- - - - P-- - PFEKVVNKESLV \\
\hline Rat & 754 & D---I---IA---HEEHRPFEKVVNKESLV \\
\hline Mouse & 754 & D---V---IV---QEEHRPFEKVVNKESLV \\
\hline
\end{tabular}

Figure 2 A comparison of the predicted amino acid sequence of the ovine insulin receptor (exons 10 through 12) with that of other species (numbered according to Ebina et al. 1985). The sequence of the exon 11 region in mouse was obtained through Genbank accession number L42997. The difference in numbering of the amino acid residues in rat and mouse compared with sheep, human and monkeys is due to two additional residues at positions 547 and 548 which are unique to the rat and mouse.

VTAAVPT in Fig. 1). To the denatured RNA was added $4 \mu \mathrm{l}$ first-strand $250 \mathrm{mM}$ Tris- $\mathrm{HCl}$ buffer $(\mathrm{pH} 8.3$ at room temperature) containing $375 \mathrm{mM} \mathrm{KCl}, 15 \mathrm{mM} \mathrm{MgCl}$ (Gibco BRL), $5 \mathrm{mM}$ dithiothreitol and $0.5 \mathrm{mM}$ dNTP and the mixture was incubated at $42{ }^{\circ} \mathrm{C}$ for $50 \mathrm{~min}$. Two control reverse transcriptions either (a) without reverse transcriptase or (b) without RNA template were performed in parallel with the samples.

An aliquot $(2-5 \mu \mathrm{l})$ of each $\mathrm{RT}$ reaction mixture was subjected to 30 cycles of PCR amplification under con- ditions known to prevent the formation of heteroduplexes (Norgren et al. 1993). Each reaction used $20 \mathrm{pmol}$ ovine species-specific sense primer CS1 (5'-TCCTGCCCG AAGACCGACTC-3') and the CA1 antisense primer which was used for reverse transcription $-200 \mu \mathrm{M}$ dNTP, $1.5 \mathrm{mM} \mathrm{MgCl}_{2}, 10 \mathrm{mM}$ Tris, $\mathrm{pH} 8.3,50 \mathrm{mM} \mathrm{KCl}$, and 0.5 units of AmpliTaq DNA polymerase. Each reaction was amplified for 30 cycles and each cycle consisted of denaturation at $95{ }^{\circ} \mathrm{C}(30 \mathrm{~s})$, annealing at $60{ }^{\circ} \mathrm{C}(30 \mathrm{~s})$ and DNA polymerisation at $72{ }^{\circ} \mathrm{C}(30 \mathrm{~s})$ in an automated thermal cycler. The final cycle included an incubation at $72{ }^{\circ} \mathrm{C}$ for $7 \mathrm{~min}$. Following amplification, $10 \mu \mathrm{l}$ of each reaction mixture was analysed by gel electrophoresis as described previously.

The percentage abundance of the alternatively spliced insulin receptor PCR products in individual tissues was calculated by scanning densitometry using Phoretix 1D Advanced (version 3.01) computer software (Phoretix International Ltd, Newcastle, UK). Statistical analysis for tissue differences was by ANOVA and the least significant differences between tissues were calculated using the Student's $t$-test. The statistical package used was Genstat 5 (NAG 1993).

\section{Results}

PCR amplification using the degenerate primers S1 and AS1 yielded two discrete PCR products of $293 \mathrm{bp}$ and $329 \mathrm{bp}$, which were consistent with the sizes of products expected from alternative splicing of the ovine insulin receptor in line with that of the human insulin receptor. The nucleotide sequences and deduced amino acid open reading frames of these products are shown in Fig. 1. The two cDNAs differ only in the inclusion of a $36 \mathrm{bp}$ sequence encoding 12 amino acids in the larger product (Fig. 1). Database homology analyses of these

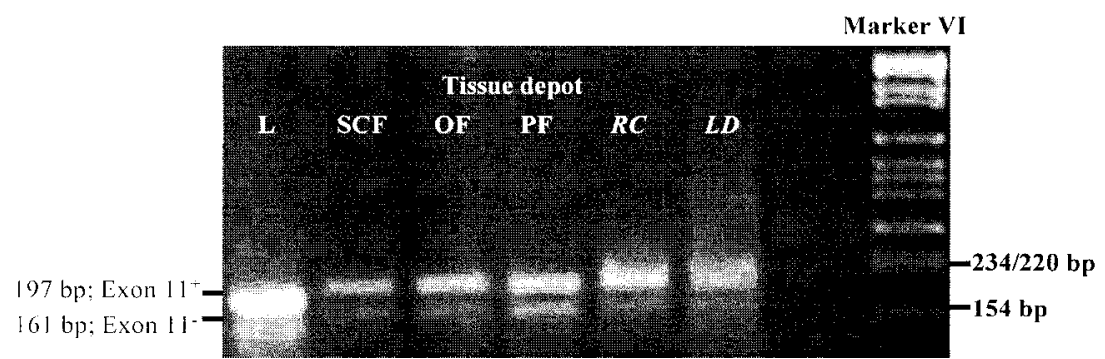

Figure 3 RT-PCR analysis for detection and determination of the relative abundance of exon 11 splice variants from a variety of tissue depots from purebred Texel male lambs (experiment 1). Ovine cDNA (from L, LD, RC, SCF, OF and PF) were used as templates, with forward (CS1) and reverse (CA1) primers designed to bind within exons 10 and 12 respectively. The exon 11 splice variant was detected due to products differing by $36 \mathrm{bp}$ in each of the lanes. Molecular weight marker VI (Boehringer Mannheim, Lewes, E. Sussex, UK) is shown on the right. Thirty cycles of PCR were performed as described in Materials and Methods and amplified products were resolved on a $\%(\mathrm{w} / \mathrm{v})$ agarose TAE gel and visualised under UV light. The relative abundance of exon $11^{+} / 11^{-}$products was determined by scanning densitometry. 

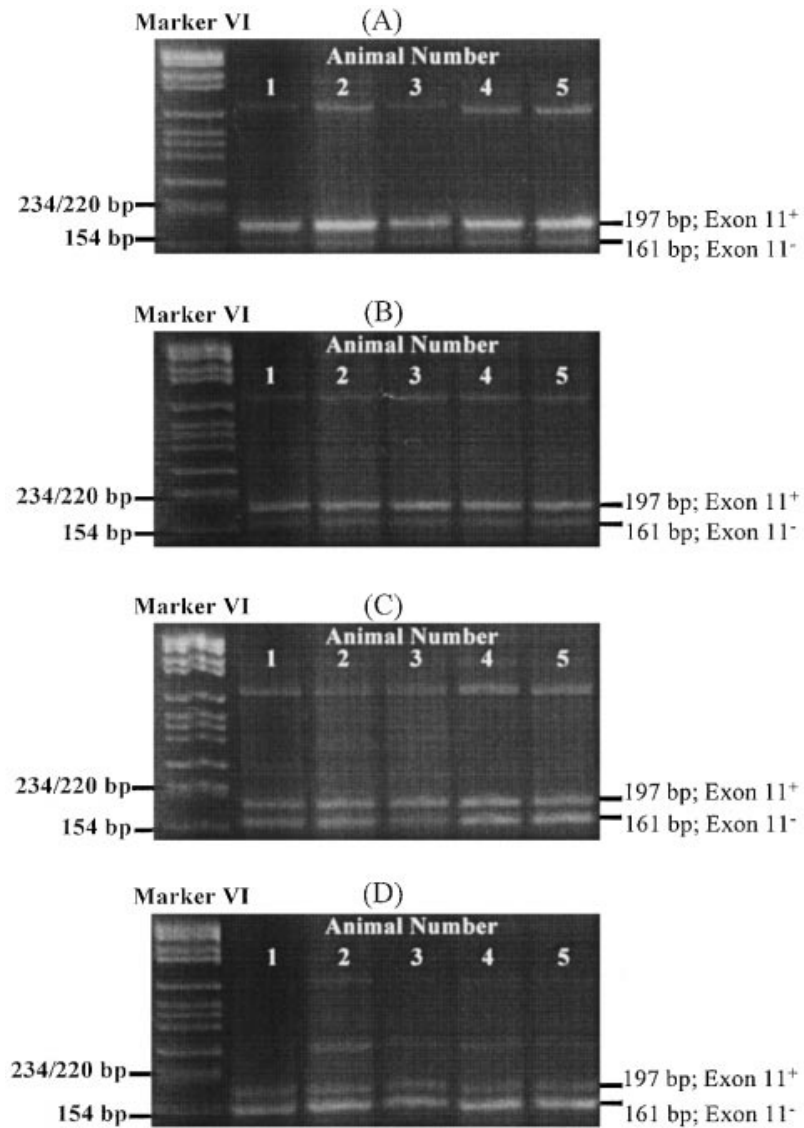

Figure 4 RT-PCR analysis for detection and determination of the relative abundance of exon 11 splice variants from a variety of tissue depots (A, liver; $B$, rectus capitis; $C$, omental flat; D, spleen) from crossbred Texel-Greyface lambs (experiment 2). Ovine cDNA from each tissue was used as a template, with forward (CS1) and reverse (CA1) primers designed to bind within exons 10 and 12 respectively. The exon 11 splice variant was detected due to products differing by $36 \mathrm{bp}$ in each of the lanes. Molecular weight marker VI (Boehringer Mannheim) is shown on the left. Thirty cycles of PCR were performed as described in Materials and Methods and amplified products were resolved on a $2 \%(\mathrm{w} / \mathrm{v})$ agarose TAE gel and visualised under UV light. The relative abundance of exon $11^{+} / 11^{-}$products was determined by scanning densitometry.

sequences confirmed that the products encoded part of the insulin receptor exon 10 and exon 12 and that the additional $36 \mathrm{bp}$ in the larger sequence was derived from exon 11.
Nucleotide and deduced amino acid sequences of the alternatively spliced ovine insulin receptor region encoding exon 10 (partial), exon 11 and exon 12 (partial) exhibited high degrees of homology with the corresponding regions from rhesus monkey $(84 \%$ and $87 \%$ respectively), human ( $84 \%$ and $86 \%$ respectively) and rat (78\% and 78\% respectively) (Fig. 2). The results of RT-PCR expression analyses and gel electrophoresis of alternatively spliced insulin receptor cDNA amplification products from some of the tissues from the male Dutch Texel lambs and from the male Texel-Greyface crossbred lambs are presented in Figs 3 and 4 respectively. All tissues gave two discrete bands representing the $\mathrm{A}$ and $\mathrm{B}$ isoforms and differing in size by exactly 36 base pairs.

Tables 1 and 2 show the relative abundance of $\mathrm{A}$ isoform and B isoform mRNA transcripts in liver, muscle, fat and spleen (Table 2 only) from the purebred Texel and crossbred Texel lambs respectively. The relative abundance of the alternatively spliced receptor isoforms differed between liver and all other tissues sampled (L vs SCF, OF: $P<0 \cdot 01$; L vs PF, RC, LD: $P<0 \cdot 05 ; n=3$, S.E.M. $=2 \cdot 055)$ in the purebred Texel lambs, but there were no significant differences in the percentage abundance of individual receptor isoforms between the skeletal muscles or between any of the fat depots or overall, between muscles and adipose tissues for this genotype. In all tissues, the B isoform was the dominant isoform, ranging from $70 \cdot 21 \%$ of total receptor mRNA in subcutaneous fat to $80.15 \%$ of total receptor mRNA in liver.

The relative abundance of the alternatively spliced receptor isoforms differed between liver and all other tissues analysed (L vs RC: $P<0 \cdot 05$; $\mathrm{L}$ vs all other tissues: $P<0 \cdot 001 ; n=5$, s.E.M $=1 \cdot 535)$ in the crossbred TexelGreyface genotype lambs. The abundance of the B isoform mRNA transcript was significantly higher in liver compared with rectus capitis skeletal muscle $(P<0 \cdot 05)$ and all other tissues $(P<0 \cdot 001)$. Spleen had the highest abundance of the A isoform mRNA transcript $(P<0 \cdot 001)$. Both skeletal muscles (rectus capitis and longissimus dorsi) had a significantly higher abundance of the $\mathrm{B}$ isoform transcript compared with any of the three adipose tissue depots $(P<0 \cdot 001)$. The relative abundance of the $\mathrm{B}$ isoform mRNA transcript was higher in rectus capitis than in longissimus dorsi $(P<0 \cdot 05)$ but there was no difference in the abundance of this transcript between any of the three adipose tissue depots.

Table 1 Percentage abundance of the two alternatively spliced insulin receptor mRNA transcripts (exon $11^{-}$ (A) and exon $11^{+}(B)$ ) in a variety of tissue depots (L, RC, LD, SCF, OF and PF) in purebred Texel male lambs

\begin{tabular}{|c|c|c|c|c|c|c|}
\hline & $\mathbf{L}$ & RC & LD & SCF & OF & $\mathrm{PF}$ \\
\hline $\mathrm{A}\left(\right.$ exon $\left.11^{-}\right)$ & $19 \cdot 85^{\mathrm{a}}$ & $27 \cdot 27^{b}$ & $26 \cdot 58^{b}$ & $29 \cdot 79^{b}$ & $29 \cdot 05^{b}$ & $28.69^{b}$ \\
\hline $\mathrm{B}\left(\operatorname{exon} 11^{+}\right)$ & $80 \cdot 15^{a}$ & $72 \cdot 73^{b}$ & $73 \cdot 42^{\mathrm{b}}$ & $70 \cdot 21^{b}$ & $70 \cdot 95^{b}$ & $71 \cdot 31^{\mathrm{b}}$ \\
\hline
\end{tabular}

Different superscripts within a row indicate tissue-specific differences $(P<0.05$ to $P<0 \cdot 001$; S.E.M. $=2 \cdot 055, n=3)$. 
Table 2 Percentage abundance of the two alternatively spliced insulin receptor mRNA transcripts (exon 11 (A) and exon $\left.11^{+}(\mathrm{B})\right)$ in a variety of tissue depots (L, RC, LD, SCF, OF, PF and S) in male Texel-Greyface lambs

\begin{tabular}{|c|c|c|c|c|c|c|c|}
\hline & $\mathbf{L}$ & RC & LD & SCF & OF & PF & S \\
\hline $\mathrm{A}\left(\operatorname{exon} 11^{-}\right)$ & $19 \cdot 58^{a}$ & $23 \cdot 02^{\mathrm{b}}$ & $28 \cdot 28^{c}$ & $46 \cdot 13^{d}$ & $46 \cdot 18^{d}$ & $47 \cdot 96^{d}$ & $30 \cdot 25^{\mathrm{e}}$ \\
\hline $\mathrm{B}\left(\right.$ exon $\left.11^{+}\right)$ & $80 \cdot 42^{a}$ & $76 \cdot 98^{\mathrm{b}}$ & $71 \cdot 72^{\mathrm{C}}$ & $53 \cdot 97^{d}$ & $53 \cdot 82^{d}$ & $52 \cdot 04^{\mathrm{d}}$ & $69 \cdot 75^{\mathrm{e}}$ \\
\hline
\end{tabular}

Different superscripts within a row indicate tissue-specific differences $(P<0 \cdot 05$ to $P<0 \cdot 01$; S.E.M. $=1 \cdot 535, n=5)$.

\section{Discussion}

In this study, we used degenerate PCR primers to screen an ovine cDNA library to determine whether alternative splicing of the insulin receptor occurs in sheep (and, by implication, in ruminant animals in general) as it does in non-ruminants. The detection of two discrete PCR products differing by exactly 36 base pairs in all the tissues sampled, confirmed that alternative splicing of the insulin receptor gene does indeed occur in sheep. Construction of two species-specific primers allowed the identification and quantification of the two mRNA transcripts of the alternatively spliced exon 11 variants, and differences in the percentage abundance of the two mRNA transcripts between a selection of insulin-sensitive tissues provides additional evidence for tissue-specific regulation of insulin receptor alternative splicing in sheep.

In both the lamb genotypes used in the study, liver contained a higher proportion of the lower affinity exon $11^{+}$isoform compared with skeletal muscle and adipose tissue. The actual physiological significance of this difference in expression of the two alternatively spliced receptor isoforms and in insulin binding affinity between liver and other tissues in ruminants (McGrattan et al. 1997, Wylie et al. 1998) is unknown, but it is considered significant that liver is exposed to portal insulin concentrations which are typically 2- to 3-fold higher than peripheral insulin concentrations. The predominance of the lower affinity exon $11^{+}$insulin receptor transcript in liver is consistent with the lower overall insulin binding affinity of this tissue in both cattle (McGrattan et al. 1997) and sheep (Wylie et al. 1998) and may allow liver to respond appropriately to fluctuating, and occasionally high, portal insulin concentrations while accommodating and permitting insulin's metabolic effects and providing significant hepatic clearance of insulin.

Although no differences in expression of alternatively spliced insulin receptor isoforms between peripheral tissues were demonstrated for the purebred Dutch Texel lambs in experiment 1, significant differences were detected both between tissues (skeletal muscle vs adipose tissue) and within tissue types in the cross-bred Texel lambs in experiment 2. It is assumed that differential distribution of the alternatively spliced insulin receptor isoforms between tissues in the cross-bred lamb genotype affects overall insulin affinity of the respective tissues and may have implications for the partitioning of nutrients between individual skeletal muscles and adipose tissue depots in these lambs. In related studies, Carson (1997) has demonstrated strong genotypic influences on carcass quality characteristics in lambs. Specifically, increasing the proportion of Texel genes $(0 ; 0.50 ; 0.75 ; 1.0)$ in a Texel-Greyface lamb population significantly increased the proportion of recoverable carcass (dressing proportion), the carcass conformation classification (grading) and the lean content of the carcass, while reducing the proportions of both intermuscular and subcutaneous fat. Reducing the fat content and improving the lean content of lamb carcasses is regarded as being of crucial importance to the future success of the extensive and intensive UK sheep industries and the genotypic influences on carcass traits shown by Carson (1997) may be related, through effects on nutrient partitioning, to primary causes such as tissue responsiveness to individual metabolic hormones.

Previous demonstrations of differences in insulin binding affinity between muscle and adipose depots of cattleand of sheep in our laboratory (McGrattan et al. 1997, Wylie et al. 1998) and of differences in the insulin binding affinity of the human A and B alternatively spliced insulin receptor isoforms when expressed in cultured cell lines (Mosthaf et al. 1990), combined with indications of tissue-specific expression of the human and rat A and B isoforms (Seino \& Bell 1989, Mosthaf et al. 1990), suggest that alternative splicing of the insulin receptor may be one mechanism by which the responsiveness of insulinsensitive tissues to insulin is modulated in ruminant and non-ruminant animals. Alteration of the ratio of expressed receptor isoforms and, hence, the overall affinity of individual tissues for insulin may influence the way in which nutrients are partitioned to, and ultimately utilised by, competing tissues (e.g. muscle, fat) and even by separate tissues of the same type (e.g. omental vs perirenal vs subcutaneous fat). It is interesting to speculate that, while the affinity of individual tissues for insulin may be specified genetically through dictation of receptor isoform ratio, it might also be manipulated by dietary-induced alteration of receptor isoform ratios through differential downregulation of the two isoforms by diet-induced hyperinsulinaemia. 
This is the first demonstration of alternative splicing of the insulin receptor gene in ruminant animals and of tissue-specific expression of the two insulin receptor gene mRNA transcripts in ruminant tissues. Identification of the nucleotide sequence encoding the exon 11 region confirms that this alternative splicing event is essentially identical to that demonstrated in humans (Ebina et al. 1985, Ullrich et al. 1985), rats (Goldstein \& Dudley 1990), and the rhesus monkey (Huang et al. 1994), and makes it possible to investigate breed and diet effects on tissuespecific expression of the insulin receptor mRNA variants in sheep and to use receptor isoform ratio as a potential marker of genotypically-related carcass traits.

\section{Acknowledgements}

The authors wish to thank Drs $M$ Travers, M Barber and R Vernon of the Hannah Research Institute, Ayr, Scotland, for their generous gift of an ovine cDNA library and the Trustees of the Agricultural Research Institute of Northern Ireland, Hillsborough, Co Down for the provision of the lambs used in the current study. P McGrattan was funded in this work by a Department of Agriculture for Northern Ireland (DANI) Postgraduate Research Studentship.

\section{References}

Altschul SF, Gish W, Miller W, Myers EW \& Lipman DJ 1990 Basic local alignment search tool. Journal of Molecular Biology 215 403-410.

Bjourson AJ \& Cooper JE 1992 Band-stab PCR: a simple technique for the purification of individual PCR products. Nucleic Acids Research 204675.

Bolinder J, Kager L, Östman J \& Arner P 1983 Differences at the receptor and postreceptor levels between human omental and subcutaneous adipose tissue in the action of insulin on lipolysis. Diabetes 32 117-123.

Breitbart RE, Andreadis A \& Nadal-Ginard B 1987 Alternative splicing: a ubiquitous mechanism for the generation of multiple protein isoforms for single genes. Annual Reviews of Biochemistry 56 467-495.

Camara M \& Mourot J 1996 Number and affinity of subcutaneous insulin receptors during growth in Large White and Meishan pigs. Proceedings of the Nutrition Society 55 66A.

Carson AF 1997 The effects of lowland ewe and ram breed type on lamb output and carcass quality. The Agricultural Research Institute of Northern Ireland 70th Annual Report, pp 24-24.

Ebina Y, Ellis L, Jarnagin K, Edery M, Graf L, Clauser E, Ou J, Masiarz F, Kan YW, Goldfine ID, Roth RA \& Rutter WJ 1985 The human insulin receptor cDNA: the structural basis for hormone-activated transmembrane signalling. Cell 40 747-758.

Goldstein BJ \& Dudley AL 1990 The rat insulin receptor: primary structure and conservation of tissue-specific alternative messenger RNA splicing. Molecular Endocrinology 4 235-244.

Hocquette JF, Bornes F, Balage M, Ferré P, Grizard J \& Vermorel M 1995 Glucose transporter (GLUT 4) protein content in oxidative and glycolytic skeletal muscles from calf and goat. Biochemical Journal $305465-470$.

Hocquette JF, Castiglia C, Ferré P \& Vermorel M 1996 Variations in GLUT 4 protein content among bovine adipose tissues. Proceedings of the Nutrition Society 55 21A.

Huang Z, Bodkin NL, Ortmeyer HK, Hansen BC \& Shuldiner AR 1994 Hyperinsulinaemia is associated with altered insulin receptor mRNA splicing in muscle of the spontaneously obese diabetic rhesus monkey. Journal of Clinical Investigation 94 1289-1296.

Kahn RC 1978 Insulin resistance, insulin insensitivity, and insulin unresponsiveness: a necessary distinction. Metabolism 27 1893-1902.

Kotzke G, Schutt M, Missler U, Moller DE, Fehm HL \& Klein HH 1995 Binding of human, porcine and bovine insulin to insulin receptors from human brain, muscle and adipocytes and to expressed recombinant alternatively spliced insulin receptor isoforms. Diabetologia 38 757-763.

McGrattan PD, Wylie ARG, Steen RWJ \& Nelson J 1997 Tissue-specific differences in insulin receptor characteristics in the mature bovine animal. Proceedings of the British Society of Animal Science, p 51A.

Moller DE, Yokota A, Caro JF \& Flier JS 1989 Tissue-specific expression of two alternatively spliced insulin receptor mRNAs in man. Molecular Endocrinology 3 1263-1269.

Mosthaf L, Grako K, Dull TJ, Coussens L, Ullrich A \& McClain DA 1990 Functionally distinct insulin receptors generated by tissuespecific alternative splicing. EMBO Journal 9 2409-2413.

NAG (National Algorithmic Group) 1993 Genstat Reference Manual Release 5, Oxford Science Publications. Oxford: Clarendon Press.

Nocek JE \& Tamminga S 1991 Site of digestion of starch in the gastrointestinal tract of dairy cows and its effect on milk yield and composition. Journal of Dairy Science 74 3598-3629.

Norgren S, Zierath J, Galuska D, Wallberg-Henriksson H \& Luthman H 1993 Differences in the ratio of RNA encoding two isoforms of the human insulin receptor between control and NIDDM patients. Diabetes 42 675-681.

Sasaki S 1989 Insulin resistance in ovine skeletal muscle: insulin binding and insulin action. Asian-Australian Journal of Animal Science $2218-219$.

Seino S \& Bell GI 1989 Alternative splicing of the human insulin receptor mRNA. Biochemical and Biophysical Research Communications 159 312-316.

Sesti G, Tullio A, Alfonso RD, Napolitano ML, Marini MA, Borboni P, Longhi R, Albonici L, Fusco A, Aglianò AM, Manzari V \& Lauro R 1994 Tissue-specific expression of two alternatively spliced isoforms of the human insulin receptor protein. Acta Diabetologica 31 $59-65$.

Ullrich A, Bell JB, Chen EY, Herrera R, Petruzzelli LL, Dull TJ, Gray A, Coussens L, Liao YC, Tsubokawa M, Mason A, Seeberg PH, Grunfeld C, Rosen OM \& Ramachandran J 1985 Human insulin receptor and its relationship to the tyrosine kinase family of oncogenes. Nature 313 756-761.

Vernon RG, Finley E, Taylor E \& Flint DJ 1985 Insulin binding and action on bovine adipocytes. Endocrinology 116 1195-1199.

Wylie ARG, McGrattan PD \& Nelson J 1998 Insulin receptor characteristics in ruminant animals. Effects of breed, sex and stage of development. In Energy Metabolism of Farm Animals, pp 111-114. Eds KJ McCracken, EF Unsworth \& ARG Wylie. Wallingford, $\mathrm{UK}$ : CAB International.

Received 30 March 1998

Revised manuscript received 30 June 1998

Accepted 24 July 1998 